\section{Pacific Northwest}

National Laboratory

Operated by Battelle for the

U.S. Department of Energy

\title{
Aquifer Testing Recommendations for Supporting Phase II of the T-Area Technetium-99 Data Objectives Process
}

\section{Letter Report}

\author{
F.A. Spane
}

March 2008

Prepared for the U.S. Department of Energy under Contract DE-AC05-76RL01830 


\title{
DISCLAIMER
}

This report was prepared as an account of work sponsored by an agency of the United States Government. Neither the United States Government nor any agency thereof, nor Battelle Memorial Institute, nor any of their employees, makes any warranty, express or implied, or assumes any legal liability or responsibility for the accuracy, completeness, or usefulness of any information, apparatus, product, or process disclosed, or represents that its use would not infringe privately owned rights. Reference herein to any specific commercial product, process, or service by trade name, trademark, manufacturer, or otherwise does not necessarily constitute or imply its endorsement, recommendation, or favoring by the United States Government or any agency thereof, or Battelle Memorial Institute. The views and opinions of authors expressed herein do not necessarily state or reflect those of the United States Government or any agency thereof.

\author{
PACIFIC NORTHWEST NATIONAL LABORATORY \\ operated by \\ BATTELLE \\ for the \\ UNITED STATES DEPARTMENT OF ENERGY \\ under Contract DE-ACO5-76RL01830
}

Printed in the United States of America
Available to DOE and DOE contractors from the
Office of Scientific and Technical Information,
P.O. Box 62, Oak Ridge, TN 37831-0062;
ph: (865) 576-8401
fax: (865) 5765728
email: reports@adonis.osti.gov

\footnotetext{
Available to the public from the National Technical Information Service, U.S. Department of Commerce, 5285 Port Royal Rd., Springfield, VA 22161 ph: (800) 553-6847 fax: (703) 605-6900

email: orders@nits.fedworld.gov online ordering: http://www.ntis.gov/ordering.htm
} 


\section{Aquifer Testing Recommendations for Supporting Phase II of the T Area Technetium-99 Data Objectives Process}

\section{Letter Report}

F.A. Spane

March 2008

Prepared for the U.S. Department of Energy under Contract DE-AC05-76RL01830

Pacific Northwest National Laboratory

Richland, Washington 99352 


\section{Summary}

Aquifer characterization needs are currently being assessed to optimize pump-and-treat remedial strategies within the 200-ZP-1 operable unit, specifically for the immediate area of the 241-T Tank Farm. Currently, two extraction wells are actively used in the 241-T Tank Farm pump-and-treat system: wells 299-W11-45 and 299-W11-46. This pump-and-treat system is operated for the purpose of remediating the existing technetium-99 (Tc-99) contamination in groundwater within this area.

Based on results of the aquifer characterization assessment, the following six hydrologic test methods were identified as having the potential for improving the design and operation of the 241-T Tank Farm pump-and-treat system:

- Multi-well, forced-gradient tracer test

- Multi-well, convergent (pump-and-treat) tracer test

- Supplemental slug tests within completed monitor wells

- Dynamic electromagnetic flowmeter surveys within completed monitor well locations

- Detailed test/depth interval slug test characterization during the drilling of new wells

- Large-scale hydrologic test characterization using the water-level recovery/rebound analysis after pumping in the 241-T Tank Farm pump-and-treat extraction wells is terminated.

Of these test methods, the large-scale water-level recovery after pumping in the 241-T Tank Farm pumpand-treat extraction wells is terminated is identified as providing the most important hydrologic information for improving the design of the remediation system, particularly as it relates to siting additional pump-and-treat system extraction wells. The analysis of areal recovery water-level responses provides an opportunity for obtaining detailed, large-scale information for a wide range of hydrologic properties (i.e., transmissivity, hydraulic conductivity, vertical and horizontal anisotropy, storativity, and specific yield). Many of these properties cannot be reliably estimated using standard single-well tests or hydrologic tests of short duration.

The letter report provides a general discussion of the six identified hydrologic test methods for possible subsequent characterization within the 241-T Tank Farm area and details for implementing the large-scale recovery test after terminating pumping at the 241-Tank Farm extraction well locations. Specifically, Section 2 identifies available well information and recently conducted hydrologic characterization tests that have been performed for T Tank Farm test wells. Section 3 discusses the six hydrologic test characterization methods identified above and particularly as they relate to numerical modeling information needs for the 241-T Tank Farm area (i.e., improving contaminant transport and capture and optimizing pump-and-treat strategies). Section 4 provides test plan details for implementing the largescale recovery test following shut-down of the 241-T Tank Farm pump-and-treat system. 



\section{Contents}

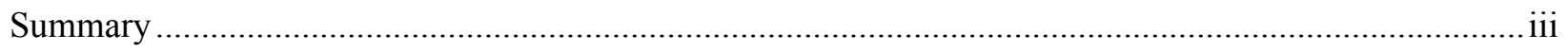

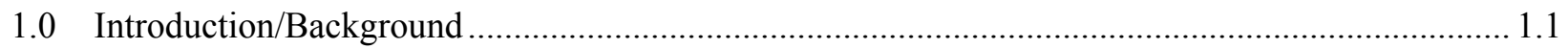

2.0 Available T Tank Farm Hydraulic Characterization Information ............................................... 2.1

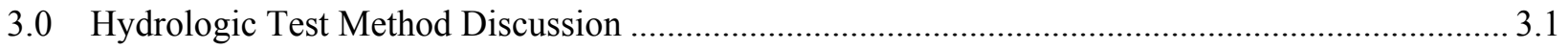

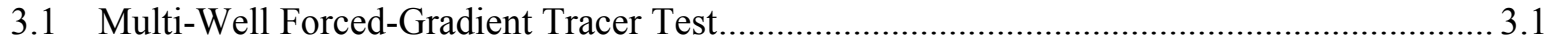

3.2 Multi-Well Convergent (Pump-and-Treat) Tracer Test......................................................... 3.1

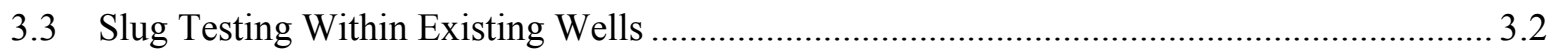

3.4 Dynamic Electromagnetic Flowmeter Surveys ............................................................. 3.2

3.5 Progressively Drill/Slug Tested Characterization Boreholes .............................................. 3.3

3.6 Large-Scale Areal Recovery Test (Shut-Down of 241-T Pump-and-Treat System) .............. 3.3

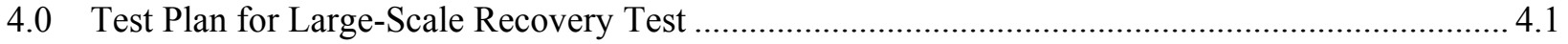

4.1 Terminating Pumping at Well 299-W11-45 ......................................................................... 4.1

4.2 Terminating Pumping and Detailed Recovery Monitoring Surrounding Well 299-W11-46 .. 4.2

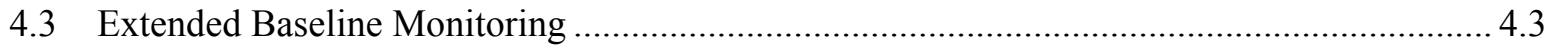

4.4 Re-Establishment of Pumping at 241-T Tank Farm Extraction Wells .................................. 4.3

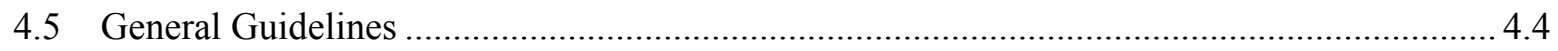

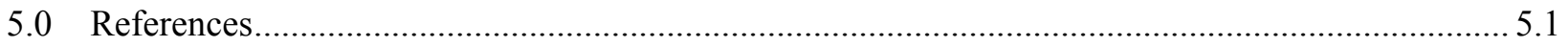

\section{Figures}

1.1. Location Map Showing T Tank Farm Well Sites ............................................................................ 1.1

2.1. Hydraulic Conductivity Histogram for Recently Tested T Tank Farm Area Wells ............................2.3

2.2. Hydraulic Conductivity and Technetium-99 Profile Data at Borehole 299-W11-25B.................. 2.4

\section{Tables}

2.1. Pertinent Survey and Completion Information for $\mathrm{T}$ Tank Farm Wells

2.2. T Tank Farm Well Slug-Test Analysis Results 


\subsection{Introduction/Background}

Fluor Hanford, Inc. is currently assessing aquifer characterization needs to optimize pump-and-treat remedial strategies in the 200-ZP-1 operable unit (OU), specifically for the immediate area of the 241-T Tank Farm. In addition, Fluor Hanford is focusing on identifying the optimum location for planned characterization well T-6 that will be used to further refine the 3-dimensional distribution of technetium$99\left({ }^{99} \mathrm{Tc}\right)$ within the area and will potentially be used as an additional pump-and-treat extraction well location. Currently, two extraction wells are actively used in the 241-T Tank Farm pump-and-treat system: wells 299-W11-45 and 299-W11-46 (Figure 1.1). These two extraction wells were activated and placed within the pump-and-treat system beginning in September 2007.

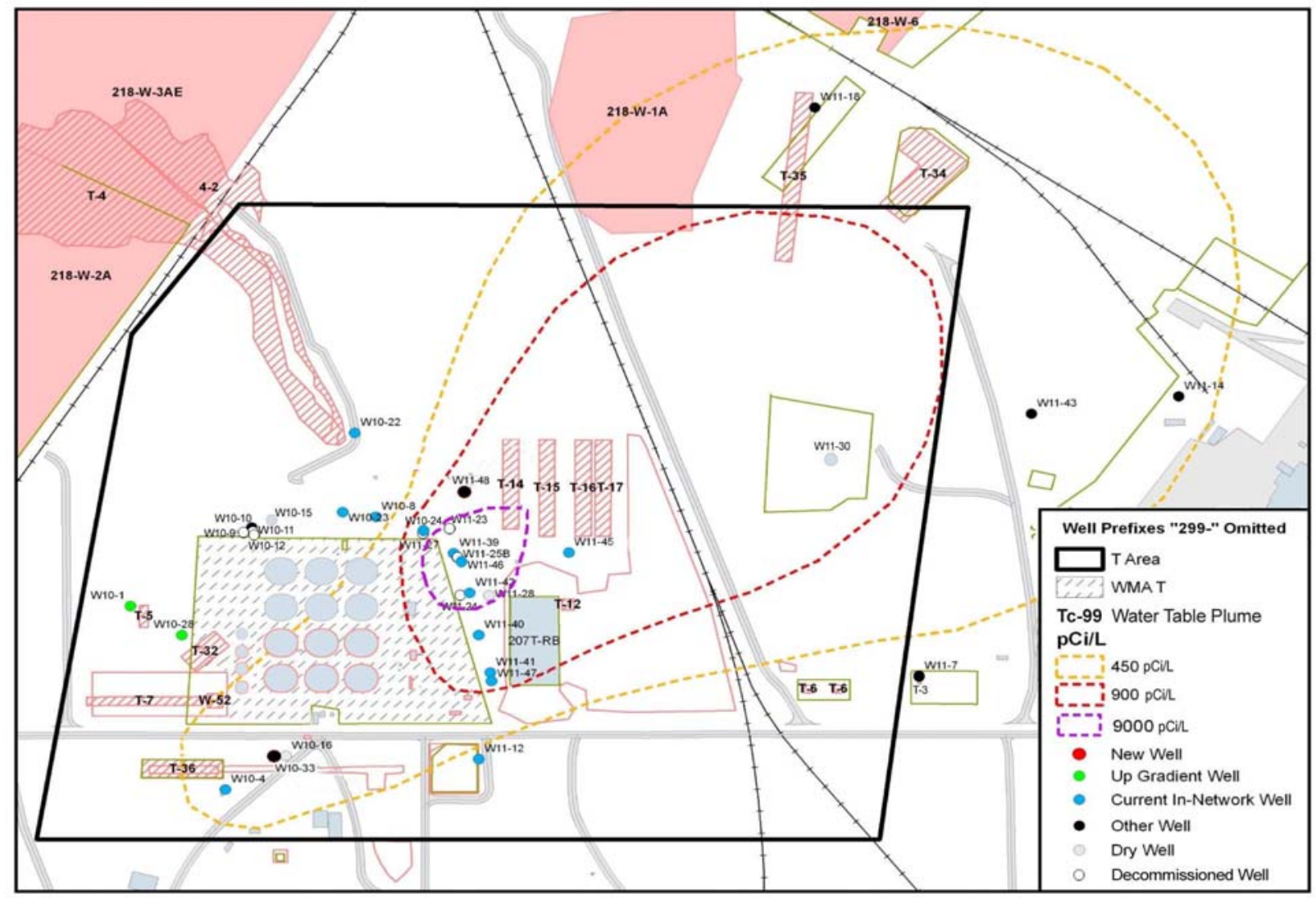

Figure 1.1. Location Map Showing T Tank Farm Well Sites

Meetings were held on February 11 and 20, 2008, with staff and consultants of Fluor Hanford, CH2M Hill Hanford Group, Inc.(CHG), the U.S. Environmental Protection Agency (EPA), and Pacific Northwest National Laboratory (PNNL) to help identify specific aquifer tests that would provide needed characterization information to support optimization of the pump-and-treat system. ${ }^{(a)}$ Based on these

(a) V. Rohay. 2008. Personal communication: "Decision-maker meeting supporting Phase II of the T-Area technetium-99 data quality objectives process: Aquifer testing for FY08." Fluor Hanford Meeting Minutes, February 11, 2008. 
meeting discussions, the following six hydrologic test methods were identified as having the potential for improving the design and operation of the 241-T Tank Farm pump-and-treat system:

- Multi-well, forced-gradient tracer test

- Multi-well, convergent (pump-and-treat) tracer test

- Supplemental slug tests within completed monitor wells

- Dynamic electromagnetic flowmeter surveys within completed monitor well locations

- Detailed test/depth interval slug test characterization during the drilling of new wells

- Large-scale hydrologic test characterization using the water-level recovery/rebound analysis after terminating the pumping of 241-T Tank Farm pump-and-treat extraction wells. 


\subsection{Available T Tank Farm Hydraulic Characterization Information}

As an initial step of the hydrologic test method assessment, a review of available well information and recently conducted hydrologic characterization tests was performed for T Tank Farm test wells. Table 2.1 lists pertinent completion and distance/location information for various monitor and extraction wells, while Table 2.2 lists available hydraulic property (hydraulic conductivity) information for hydrologic tests previously conducted within the T Tank Farm area during FY 1999 to FY 2007. As indicated in Table 2.2, 11 well sites have reported slug-test characterization results within the T Tank Farm area. In addition, three T Tank Farm well site locations have had short-duration (i.e., 245 to 345 minutes) multiwell pumping tests performed. The inter-well hydraulic conductivity estimates obtained from the multiwell pumping tests compare very favorably with the single-well slug tests conducted at these well sites (Table 2.2).

Table 2.1. Pertinent Survey and Completion Information for $T$ Tank Farm Wells

\begin{tabular}{|c|c|c|c|c|c|}
\hline \multirow[b]{2}{*}{$\begin{array}{c}\text { T Tank } \\
\text { Farm Wells }\end{array}$} & \multicolumn{2}{|c|}{$\begin{array}{c}\text { NAD83 (91) } \\
\text { Horizontal Coordinate } \\
\text { Survey } \\
\end{array}$} & \multirow{2}{*}{$\begin{array}{c}\text { NAVD(88) } \\
\text { Elevation } \\
\text { Survey } \\
\text { Brass Cap, } \\
\text { m MSL } \\
\end{array}$} & \multirow{2}{*}{$\begin{array}{c}\text { Well-Screen } \\
\text { Elevation, m } \\
\text { MSL } \\
\text { (Top - Bottom) }\end{array}$} & \multirow{2}{*}{$\begin{array}{c}\text { Radial Distance from } \\
\text { Well 299-W11-46, } \\
\text { m }\end{array}$} \\
\hline & $\begin{array}{l}\text { North, } \\
\text { m }\end{array}$ & $\begin{array}{c}\text { East, } \\
\text { m }\end{array}$ & & & \\
\hline 2-W10-23 & 136815.34 & 566823.73 & 206.69 & $137.87-127.17$ & 100.37 \\
\hline 2-W10-24 & 136798.78 & 566885.43 & 208.98 & $137.98-127.28$ & 38.95 \\
\hline $2-W 10-28$ & 136709.93 & 566701.55 & 206.10 & $137.98-127.28$ & 222.52 \\
\hline 2-W10-33 & 136610.19 & 566772.75 & 205.12 & $86.25-80.15$ & 216.31 \\
\hline 2-W11-39 & 136779.92 & 566908.38 & 209.89 & $137.16-126.48$ & 9.28 \\
\hline $2-W 11-40$ & 136709.67 & 566926.84 & 209.70 & $137.13-126.45$ & 64.72 \\
\hline 2-W11-41 & 136677.78 & 566935.51 & 209.67 & $137.52-126.86$ & 97.70 \\
\hline $2-W 11-42$ & 136745.67 & 566920.44 & 210.18 & $138.02-127.34$ & 28.16 \\
\hline $2-W 11-45$ & 136775.64 & 566992.84 & 212.88 & $127.15-122.70$ & 78.02 \\
\hline $2-W 11-46$ & 136773.27 & 566914.86 & 210.12 & $129.84-123.74$ & 0.00 \\
\hline 2-W11-47 & 136680.70 & 566933.82 & 209.66 & $126.07-116.76$ & 94.49 \\
\hline 2-W11-48 & 136846.18 & 566881.97 & 208.90 & $124.33-96.88$ & 79.99 \\
\hline
\end{tabular}


Table 2.2. T Tank Farm Well Slug-Test Analysis Results

\begin{tabular}{|c|c|c|c|c|c|c|}
\hline \multirow[b]{2}{*}{$\begin{array}{c}\text { T Tank } \\
\text { Farm Wells }\end{array}$} & \multicolumn{3}{|c|}{ Slug Test Characterization } & \multicolumn{2}{|c|}{$\begin{array}{l}\text { Pumping Test } \\
\text { Characterization }\end{array}$} & \multirow[b]{2}{*}{$\begin{array}{c}\text { Data Source/ } \\
\text { Comments }\end{array}$} \\
\hline & Test Date & $\begin{array}{l}\text { Water-Table } \\
\text { Elevation, } \\
\text { m MSL }\end{array}$ & $\begin{array}{c}\text { Best } \\
\text { Estimate } \\
\mathbf{K}, \mathbf{m} / \text { day }\end{array}$ & Test Date & \begin{tabular}{|c|} 
Best \\
Estimate K, \\
m/day
\end{tabular} & \\
\hline $2-W 10-23$ & $1 / 8 / 1999$ & 138.19 & 2.35 & NT & \begin{tabular}{|l|} 
NT \\
\end{tabular} & Spane et al. (2001a) \\
\hline $2-W 10-24$ & $1 / 11 / 1999$ & 138.11 & 1.68 & $4 / 21 / 1999$ & 1.22 & $\begin{array}{l}\text { Spane et al. (2001a); } \\
245 \text { min multi-well } \\
\text { pumping test }\end{array}$ \\
\hline $2-W 10-28$ & $12 / 12 / 2001$ & 137.21 & 27.90 & NT & NT & Spane et al. (2002) \\
\hline $2-W 10-33$ & $7 / 6 / 2007$ & 135.14 & 15.70 & NT & NT & $\begin{array}{l}\text { Newcomer (2007); } \\
\text { result for shallow } \\
\text { aquifer depth interval } \\
\text { tested during drilling; } \\
\text { current well-screen } \\
\text { completion has not } \\
\text { been tested. }\end{array}$ \\
\hline $2-W 11-25 B$ & $2 / 9 / 2005$ & 136.00 & 4.73 & NT & NT & $\begin{array}{l}\text { Spane and Newcomer } \\
\text { (2008); result for } \\
\text { shallow aquifer depth } \\
\text { interval tested during } \\
\text { drilling; well was } \\
\text { destroyed and de- } \\
\text { commissioned during } \\
\text { well completion. }\end{array}$ \\
\hline 2-W11-39 & $2 / 15 / 2001$ & 137.23 & 1.69 & $9 / 27 / 2001$ & $0.85-1.64$ & $\begin{array}{l}\text { Spane et al. (2002); } \\
305 \text { min multi-well } \\
\text { pumping test }\end{array}$ \\
\hline $2-W 11-40$ & $2 / 13 / 2001$ & 137.27 & 4.58 & $8 / 9 / 2001$ & $1.76-2.25$ & $\begin{array}{l}\text { Spane et al. (2002); } \\
345 \text { min multi-well } \\
\text { pumping test }\end{array}$ \\
\hline 2-W11-41 & $11 / 13 / 2000$ & 137.38 & 7.78 & NT & NT & Spane et al. (2001b) \\
\hline $2-W 11-42$ & $11 / 8 / 2000$ & 137.53 & 28.10 & NT & NT & Spane et al. (2001b) \\
\hline $2-W 11-45$ & $\begin{array}{l}9 / 27 / 2005- \\
11 / 15 / 2005\end{array}$ & 135.80 & $\begin{array}{c}\text { (see } \\
\text { comments) }\end{array}$ & NT & NT & $\begin{array}{l}\text { Undocumented result } \\
\text { for five aquifer depth } \\
\text { intervals tested } \\
\text { during drilling; } \\
\text { current well-screen } \\
\text { completion has not } \\
\text { been tested. }\end{array}$ \\
\hline $2-W 11-46$ & $9 / 21 / 2005$ & 136.29 & 3.78 & NT & NT & $\begin{array}{l}\text { Spane and Newcomer } \\
(2008)\end{array}$ \\
\hline $2-W 11-47$ & $\begin{array}{c}2 / 16 / 2006- \\
3 / 23 / 2006\end{array}$ & 135.53 & $\begin{array}{c}\text { (see } \\
\text { comments) }\end{array}$ & NT & NT & $\begin{array}{l}\text { Undocumented result } \\
\text { for four aquifer depth } \\
\text { intervals tested } \\
\text { during drilling; } \\
\text { current well-screen }\end{array}$ \\
\hline
\end{tabular}


Table 2.2. T Tank Farm Well Slug-Test Analysis Results

\begin{tabular}{|c|c|c|c|c|c|c|}
\hline \multirow[b]{2}{*}{$\begin{array}{c}\text { T Tank } \\
\text { Farm Wells }\end{array}$} & \multicolumn{3}{|c|}{ Slug Test Characterization } & \multicolumn{2}{|c|}{$\begin{array}{c}\text { Pumping Test } \\
\text { Characterization }\end{array}$} & \multirow[b]{2}{*}{$\begin{array}{c}\text { Data Source/ } \\
\text { Comments }\end{array}$} \\
\hline & Test Date & $\begin{array}{c}\text { Water-Table } \\
\text { Elevation, } \\
\text { m MSL }\end{array}$ & $\begin{array}{c}\text { Best } \\
\text { Estimate } \\
\text { K, m/day }\end{array}$ & Test Date & \begin{tabular}{|c|} 
Best \\
Estimate K, \\
m/day
\end{tabular} & \\
\hline & & & & & & $\begin{array}{l}\text { completion has not } \\
\text { been tested. }\end{array}$ \\
\hline 2-W11-48 & $4 / 6 / 2007$ & 135.26 & 1.24 & NT & NT & $\begin{array}{l}\text { Newcomer (2007); } \\
\text { result for shallow } \\
\text { aquifer depth interval } \\
\text { tested during drilling; } \\
\text { current well-screen } \\
\text { completion has not } \\
\text { been tested. }\end{array}$ \\
\hline & $4 / 12 / 2007$ & 135.11 & 6.27 & NT & NT & \\
\hline
\end{tabular}

Figure 2.1 shows a histogram distribution of hydraulic conductivity values for slug tests conducted within the top (i.e., upper 10 meters) of the unconfined aquifer. These tests are reflective of the Ringold Formation gravel unit E. As shown in the figure, the histogram distribution appears to conform to a lognormal distribution, with a hydraulic conductivity range between 1.24 and $28.1 \mathrm{~m} /$ day and a geometric mean of $5.22 \mathrm{~m} /$ day. These hydraulic conductivity values compare favorably to the range $(0.05$ to 64.1 $\mathrm{m} /$ day) and geometric mean $(3.43 \mathrm{~m} /$ day) previously reported for slug-test characterization performed for all wells within the entire 200-West Area (Spane and Newcomer 2008).

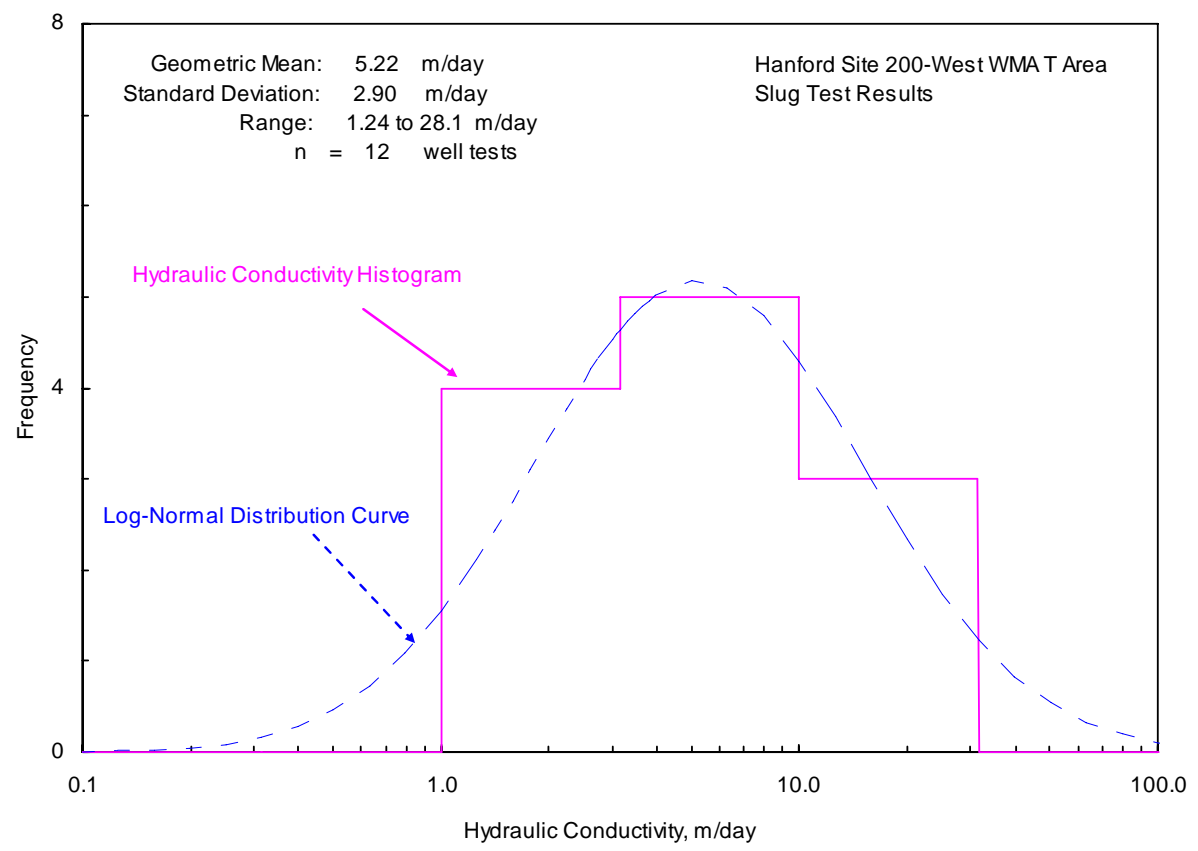

Figure 2.1. Hydraulic Conductivity Histogram for Recently Tested T Tank Farm Area Wells 
In addition to these 11 well sites, three of the T Tank Farm test wells have been progressively slug tested during the course of borehole drilling. This type of characterization was designed to provide an assessment of the variation and vertical distribution of hydraulic conductivity and hydrochemical contamination with depth within the unconfined aquifer at these specific locations. This type of characterization information is important for predicting/simulating contaminant migration (i.e., numerical flow/transport modeling) and designing proper monitor well strategies for specific OU locations. The specific test sites where detailed depth/interval slug test characterization was previously conducted include the following wells: 299-W11-25B, 299-W11-45, and 299-W11-47. Results obtained for well 299-W11-25B were obtained in support with Site-Wide Resource Conservation and Recovery Act (RCRA) Waste Management Area (WMA) testing activities and are reported in Spane and Newcomer (2008). Figure 2.2 shows a comparison plot of hydraulic conductivity and ${ }^{99} \mathrm{Tc}$ contaminant levels. When combined with results reported in Spane et al. (2002) for nearby well 299-W11-39 (distance $=9.3$ $\mathrm{m}$ ), approximately $40 \%$ of the composite unconfined aquifer has been characterized for hydraulic conductivity vs. depth at this test site location. As indicated in Figure 2.1, higher ${ }^{99}$ Tc contaminant vs. depth values appear to be visually correlated with higher values of hydraulic conductivity, K, within the unconfined aquifer.

The testing of wells 299-W11-45 and 299-W11-47 was outside RCRA characterization funding activities and were not previously analyzed or documented as part of this program. These test data are available, however, and can be analyzed to provide hydraulic conductivity depth-profile information for these two $\mathrm{T}$ Tank Farm well site locations.

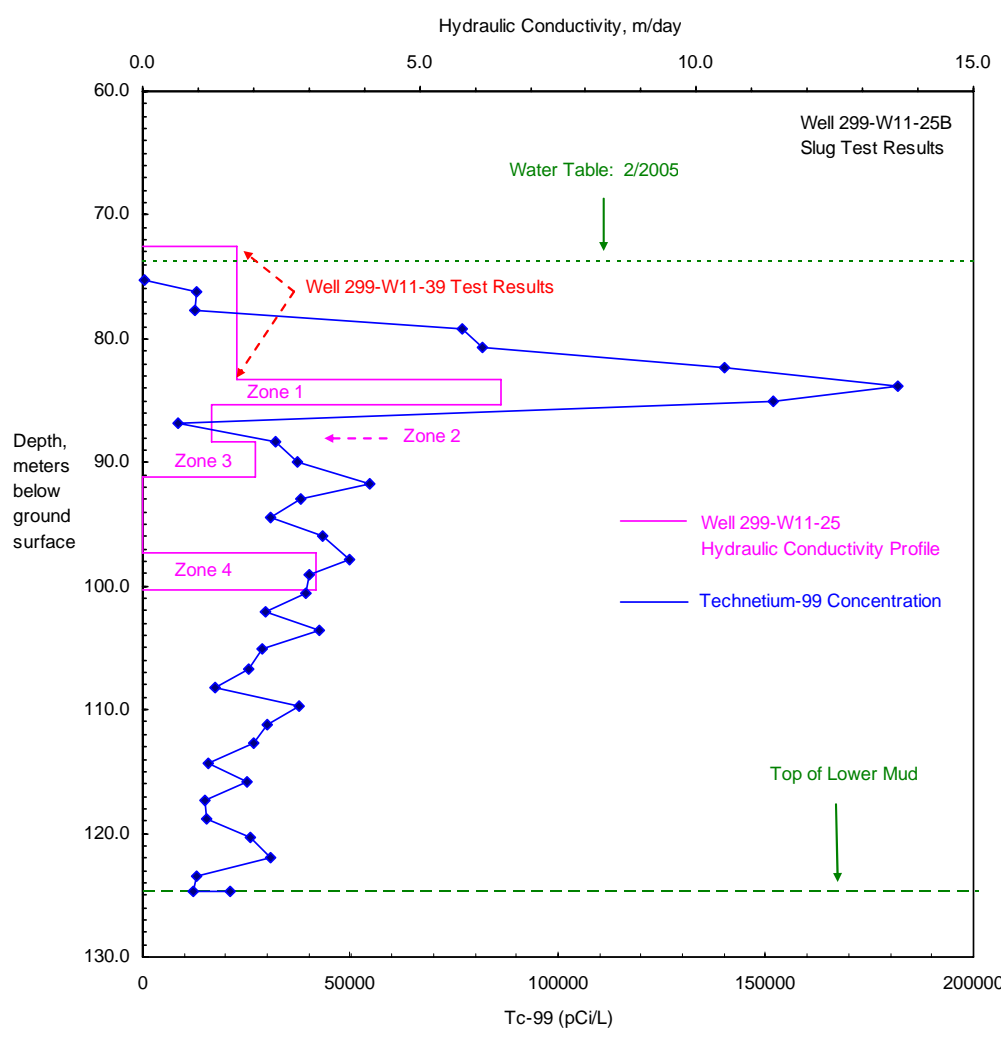

Figure 2.2. Hydraulic Conductivity and Technetium-99 Profile Data at Borehole 299-W11-25B 


\subsection{Hydrologic Test Method Discussion}

The following discussion pertains to the six hydrologic test characterization methods identified in the Introduction/Background section that were identified for possible consideration during the February 2008 $\mathrm{T}$ Tank Farm data needs meetings. These hydrologic test methods are discussed with their relevance to information that could be provided, if implemented, as they relate to numerical modeling needs for the 241-T Tank Farm area (i.e., improving contaminant transport and capture and optimizing pump-and-treat strategies). Based on a relative test method comparison, it is recommended that the large-scale areal recovery test (Section 3.6) be implemented first for improving the overall hydraulic characterization information available for this specific Hanford location. Base on an analysis of these areal recovery test results, additional hydrologic test methods (presented below) may be considered for improving contaminant capture and optimizing the pump-and-treat system performance.

\subsection{Multi-Well Forced-Gradient Tracer Test}

Multi-well, forced-gradient tracer tests require the presence of a nearby injection and extraction well couplet to establish a high, inter-well hydraulic gradient to transport a conservative tracer (e.g., bromide) during the period of testing. If the inter-well hydraulic properties are known from previous hydraulic characterization tests, the tracer arrival and breakthrough profile characteristics at the extraction well can be analyzed to provide information concerning aquifer longitudinal dispersivity and effective porosity. These are important parameters for optimizing the design of contaminant capture using pump-and-treat systems. A review of existing T Tank Farm wells (Figure 1.1), however, indicates only two adjacent wells (couplet: well 299-W11-39/W11-46 and 299-W11-42/W11-46) that have the required inter-well distance relationships (9.3 and $28.2 \mathrm{~m}$, respectively; Table 2.1) that would allow full tracer breakthrough over a reasonable testing time period (e.g., 2 to 6 weeks). In addition, the available well couplets have overlapping well-screen depth/elevation conditions (Table 2.1), which adds a level of uncertainty to the tracer-test analysis results. For these reasons, it is recommended that a multi-well, forced-gradient tracer test be considered for future characterization activities when additional wells may be available with more favorable completion and distance relationships within the T Tank Farm area. An example of a successfully conducted multi-well, forced-gradient tracer test that was directly part of remedial action activities performed at the Hanford Site is presented in a letter report by Spane and Newcomer. ${ }^{(a)}$

\subsection{Multi-Well Convergent (Pump-and-Treat) Tracer Test}

Like the multi-well, forced-gradient tracer test, a convergent tracer test provides information concerning aquifer longitudinal dispersivity and effective porosity and requires the presence of relatively closely located wells surrounding an extraction well. This type of tracer test does not use a continuous injection well (i.e., in conjunction with the extraction well) to establish an artificially imposed, high hydraulic gradient condition, and as a consequence, tracer-test arrival times may be considerably longer for full tracer breakthrough and recovery. An attractive advantage for this type of tracer test, however, is that it could be performed in concert with ongoing pump-and-treat operational activities and would not require a separate hydrologic test. A review of existing well locations shown in Figure 1.1, however, indicates no

(a) FA Spane, Jr., and DR Newcomer. 2006. Hydrologic Test Characterization Results for the 100-KR-4 Calcium Polysulfide Field Site Demonstration. PNNL-letter report to SW Peterson (Project Manager Fluor-Hanford); February 28, 2006. 
viable adjacent well candidates surrounding 241-T Tank Farm extraction well 299-W11-45, and, as was discussed previously, adjacent wells located in proximity to extraction well 299-W11-46 do not have coincident well-screen completion depth/elevations (Table 2.1). For these reasons, it is recommended that an "opportunistic," convergent tracer test be considered as a future characterization activity after additional large-scale characterization tests have been conducted, and additional wells have been added within the T Tank Farm area.

\subsection{Slug Testing Within Existing Wells}

As listed in Table 2.2, slug-test characterization has been routinely conducted since FY 1999 at completed T Tank Farm monitoring well locations and has been reported in Spane et al. (2001a, 2001b, 2002, 2003) and Spane and Newcomer $(2004,2008)$ as part of ongoing RCRA site characterization activities. As shown in Table 2.2, however, four of the existing T Tank Farm wells, 299-W10-33, 299-W11-45, 299W11-47, and 299-W11-48, were not tested after final well completion. These wells should be considered for slug testing for inclusion within the characterization data set used for assessing spatial variability of hydraulic conductivity within the T Tank Farm area.

It should also be noted that the majority of the T Tank Farm test wells were tested between FY 1999 and FY 2002. Since this time, the water table has declined in excess of $1.5 \mathrm{~m}$ over current conditions. The question could be raised as to the representativeness of these earlier slug-test characterizations for the current lower water-table conditions. As a point of addressing this topic, Spane and Newcomer (2008) reported that the slug-test results collected within the general 200-West Area between FY 1999 and FY-CY 2005 provided average hydraulic conductivity estimates that were surprisingly consistent with previously cited historical hydraulic conductivity values listed for the Ringold Formation within the 200-West Area (e.g., DOE/RL 1993; 200-West Area, 0.02 to $61 \mathrm{~m} /$ day) when water-table elevations within the unconfined aquifer were significantly higher (i.e. $\geq 3 \mathrm{~m}$ ) than current conditions. This close similarity in hydraulic conductivity range suggests that the overlying (now de-saturated) Ringold Formation units possess similar areal hydraulic property characteristics as currently exhibited within the current upper $10 \mathrm{~m}$ of the unconfined aquifer within the general 200-West Area, although some local differences would likely exist. Even though this general correspondence suggests that rather similar areal hydraulic properties may exist for saturated and recently de-saturated sections of the unconfined aquifer sediments in the T Tank Farm region, it is recommended that additional, follow-up slug testing be implemented for confirmatory purposes. In addition to testing the four previously identified, un-tested $\mathrm{T}$ Tank Farm wells, it is recommended that a number of the earlier slug-tested wells near the current extraction well 299-W11-46 (e.g., 299-W11-39, 299-W11-42) be re-tested. It is suggested that the proposed slug testing at existing wells be considered as a future characterization activity after additional large-scale characterization has been conducted, and additional wells have been added within the T Tank Farm area.

\subsection{Dynamic Electromagnetic Flowmeter Surveys}

Briefly stated, dynamic electromagnetic flowmeter (EBF) surveys provide direct measurements of groundwater in-flow along the saturated well screen during a constant-rate pumping test. The various measured inflow rates vs. depth are directly related to the vertical profile of hydraulic conductivity outside the well screen within the surrounding aquifer formation. A detailed description of EBF instrumentation and application of surveys for site characterization is presented in Spane and Newcomer (2008). 
A review of available hydrologic test characterization information indicates that no dynamic EBF flowmeter surveys have been conducted in the T Tank Farm area. A number of dynamic flowmeter surveys, however, have been successfully completed to provide detailed hydraulic-conductivity vs. depthprofile information at other Hanford Site locations, e.g., 300 Area and 100-D Area (to be published in reports that are in progress). Examples of using EBF survey information to develop vertical depth profiles of hydraulic conductivity and geostatistical realizations within the surrounding aquifer materials are presented in Vermeul et al. (2004) and Li et al. (2008).

It should be noted that the level of depth profile characterization is limited by the available saturated wellscreen sections of existing wells. With this respect, Table 2.1 indicates that T Tank Farm well 299-W1148 has the largest available saturated well-screen section of $27.5 \mathrm{~m}$.; however, this section is located approximately 10 to $37.5 \mathrm{~m}$ below the current water table. If combined with other test well EBF characterization surveys (e.g., well 299-W11-39 and extraction wells 299-W11-45 and 299-W11-46), a composite areal hydraulic conductivity vs. depth profile could be developed for the upper $\sim 48 \mathrm{~m}$ of the unconfined aquifer within the 241-T Tank Farm pump-and-treat system. It is recommended that the proposed EBF characterization surveys be considered as a future characterization activity after additional large-scale characterization has been conducted, e.g., recovery following T Tank Farm pump-and-treat system shut-down. It is also recommended that any wire-wrap well screens used for new T Tank Farm well installations have at least one solid joint (i.e., $\sim 3$ inches in length). This solid joint section is useful for correcting EBF surveys for bypass flow effects between the flowmeter packer and the well screen.

\subsection{Progressively Drill/Slug Tested Characterization Boreholes}

As previously discussed in Section 3, T Tank Farm test wells 299-W11-25B, 299-W11-45, and 299-W11-47 were slug tested during the course of drilling the test wells to assess the variation and vertical distribution of hydraulic conductivity with depth within the unconfined aquifer at these specific locations. As noted previously, only one of these test wells has been analyzed with formal report documentation (i.e., well 299-W11-25B, Spane and Newcomer 2008). As shown in Figure 2.2, higher values of hydraulic conductivity, $\mathrm{K}$, appear to be visually correlated with higher contaminant levels for

${ }^{99} \mathrm{Tc}$ vs. depth at this well location. This type of characterization correlation information is important for predicting/simulating contaminant migration (i.e., numerical flow/transport modeling) and designing proper monitor well strategies for specific OU Tank Farm locations.

It is recommended that the test/depth interval results obtained during the drilling of extraction well 299W11-45 and for well 299-W11-47 be formally analyzed and documented and that this characterization method be used during the drilling of any future deep T Tank Farm wells. It is also recommended that these proposed characterization activities be considered after additional large-scale characterization testing has been conducted e.g., large-scale recovery test associated with the shut-down of the T Tank Farm pump-and-treat system.

\subsection{Large-Scale Areal Recovery Test (Shut-Down of 241-T Pump-and-Treat System)}

A number of programs have been implemented on the Hanford Site that use the pumping and treatment of contaminated groundwater as part of their remediation strategy (e.g., DOE/RL 2000). As noted in Spane 
and Thorne (2000), the implementation of remedial pump-and-treat systems results in hydraulic pressure responses both areally and vertically (i.e., with depth) within the pumped unconfined aquifer system. The distance, or radius of influence, imposed by the pump-and-treat system is a function of a number of physical factors and test-facility operation characteristics. Important physical factors include aquifer properties (i.e., hydraulic conductivity, vertical anisotropy, specific yield, aquifer thickness) and well/aquifer completion relationships (i.e., partial penetration aspect). Test-facility operation characteristics include the location, duration, magnitude, and variability of groundwater extraction and injection within the aquifer.

The analysis of areal water-level responses imposed by the 241-T Tank Farm pump-and-treat system provides an opportunity for obtaining detailed, large-scale information for a wide range of hydrologic properties (i.e., transmissivity, hydraulic conductivity, vertical and horizontal anisotropy, storativity, and specific yield). Many of these properties cannot be reliably estimated using standard single-well tests or hydrologic tests of short duration. This large-scale hydrologic characterization information can provide valuable input for assessing and optimizing the performance of the 241-T Tank Farm pump-and-treat facility and for predicting contaminant movement in this region of the 200-West Area.

Currently, two extraction wells are actively used in the 241-T Tank Farm pump-and-treat system: wells 299-W11-45 and 299-W11-46 (Figure 1.1). These wells were activated and placed within the pump-andtreat system beginning in September 2007. Pumping rates for the two extraction wells have varied since September 2007 to present, but since the end of December, the pumping rates have been relatively stable at approximately 11.7 and $37.1 \mathrm{gpm}$ for wells 299-W11-45 and 299-W11-46, respectively. It is proposed that pumping at the 241-T Tank Farm extraction wells be terminated in a controlled fashion, and the associated areal recovery pressure rebound be monitored and analyzed to provide large-scale hydraulic and storage properties. This type of large-scale hydrologic characterization is directly analogous to the successful analysis of the monitored recovery following a temporary shut-down of the 200-ZP-1 pumpand-treat system southwest of the TX-TY Tank Farm that occurred at the beginning of CY 2000, as reported and discussed in Spane and Thorne (2000).

It should be noted that an inherent assumption in hydraulic test analysis is that the well water-level responses analyzed are caused solely by the imposed hydrologic stress (i.e., the pump-and-treat system shut-down). Natural external stresses such as barometric pressure fluctuations, however, can have a discernible impact on well water-level measurements and may significantly mask waterlevel responses within more distant wells from the extraction-well locations. In those situations, it is likely that the removal of barometric pressure fluctuation effects from the well measurements will be required before quantitative hydrologic analysis of the recovery/rebound areal response. These barometric removal methods are presented in Spane and Thorne (2000) and are discussed in more detail in Rasmussen and Crawford (1997) and Spane (1999, 2002). Recommended steps and procedures for implementing the large-scale recovery test following shut-down of the 241-T pump-and-treat system are included in the following large-scale recovery test plan. 


\subsection{Test Plan for Large-Scale Recovery Test}

The following test plan is based primarily on the results and discussion contained in Spane and Thorne (2000) of the similar large-scale recovery test following shut-down of the 200-ZP-1 pump-and-treat system immediately southwest of the TX-TY Tank Farm area. This large-scale recovery test occurred at the beginning of CY 2000.

An examination of the distribution of existing monitoring wells surrounding the 241-T Tank Farm area (shown in Figure 1.1) indicates that the majority of these wells are situated more closely to extraction well 299-W11-46. Table 2.1 provides distance relationships of the surrounding monitor wells to extraction well 299-W11-46 and well-screen completion elevations. Based on the information provided in Spane and Thorne (2000) and existing well distance/completion information, the following steps/activities are recommended:

- Terminate pumping at extraction well 299-W11-45 at least 3 weeks before terminating pumping at extraction well 299-W11-46

- Following stabilization of effects from the shut-down of extraction well 299-W11-45, monitor the recovery following shut-down of extraction well 299 W11-46

- Baseline monitoring period for barometric response analysis/removal

- Monitor drawdown during re-establishment of pumping at extraction wells 299 W11-45 and 299-W11-46.

\subsection{Terminating Pumping at Well 299-W11-45}

Because of the relatively low pumping rate (i.e., $\sim 11.7 \mathrm{gpm}$ ) and the larger distance to other surrounding monitoring wells (i.e., greater than $75 \mathrm{~m}$ ), it is recommended that pumping at extraction well 299-W11-45 be terminated first, at least 3 weeks before terminating pumping and detailed monitoring of the areal recovery surrounding extraction well 299-W11-46. This early termination of pumping at well 299-W1145 is to lessen the hydrologic impact from this well and to improve the quantitative recovery analysis of monitoring wells surrounding extraction well 299-W11-46. The frequency of measuring the recovery of pumping well 299-W11-45 following cessation of pumping at this well location should be as often as possible during the early recovery stages if an automated datalogger/in-well pressure transducer system is deployed. Ideally, the in-well recovery pressure measurement frequency within well 299-W11-45 should follow these monitoring guidelines:

- 0 to 1 minutes: frequency = every 1 to $2 \mathrm{sec}$

- 1 to 3 minutes: frequency $=$ every $5 \mathrm{sec}$

- 3 to 5 minutes: frequency $=$ every $10 \mathrm{sec}$ 
- 5 to 10 minutes: frequency $=$ every $15 \mathrm{sec}$

- 10 to 20 minutes:: frequency $=$ every $20 \mathrm{sec}$

- 20 to 30 minutes: frequency $=$ every $30 \mathrm{sec}$

- 30 to 60 minutes: frequency = every $\min$

- 1 to 2 hours: frequency = every $2 \mathrm{~min}$

- 2 to 4 hours: frequency $=$ every $5 \mathrm{~min}$

- 4 to 8 hours: frequency = every $10 \mathrm{~min}$

- $>8$ hours: frequency $=$ every $15 \mathrm{~min}$.

If an automated recording system is not available at well 299-W11-45 (i.e., only a visual monitor and manual recording capability) then in-well pressure readings should be taken as quickly as possible during the first 3 to 5 minutes of recovery, and the following recording frequency should be maintained: every 30 secs until $10 \mathrm{~min}$; every $1 \mathrm{~min}$ from 10 to $20 \mathrm{~min}$ of recovery; every $2 \mathrm{~min}$ from 20 to $30 \mathrm{~min}$ of recovery; every $3 \mathrm{~min}$ from 30 to $42 \mathrm{~min}$ of recovery; every $4 \mathrm{~min}$ from 42 to $50 \mathrm{~min}$ of recovery; every 5 $\mathrm{min}$ from 50 to $70 \mathrm{~min}$ of recovery; every $10 \mathrm{~min}$ from 70 to $120 \mathrm{~min}$ of recovery; and every 15 to $20 \mathrm{~min}$ after $120 \mathrm{~min}$.

No formal recovery analysis will be attempted at the other surrounding monitoring wells because of their relative distance and proximity to the ongoing pumping occurring at extraction well 299-W11-46. Nevertheless, a recovery pressure perturbation may be exhibited at these distant well sites and be useful for planning purposes for the subsequent formal recovery analysis associated with termination of pumping at extraction well 299-W11-46. With this regard, if an automated datalogger/in-well pressure transducer system is available at the nearest surrounding T Tank Farm wells (e.g., well 299-W11-39, 299-W11-46), then the following general measurement frequency guidelines are recommended at these well sites during the recovery following shut-down of extraction well 299-W11-45: every $10 \mathrm{sec}$ for the first $5 \mathrm{~min}$ to $60 \mathrm{~min}$ of recovery and then 10 to $15 \mathrm{~min}$ after 1 hour.

\subsection{Terminating Pumping and Detailed Recovery Monitoring Surrounding Well 299-W11-46}

It is recommended that termination of pumping at extraction well 299-W11-46 and the formal monitoring of recovery at surrounding T Tank Farm monitoring wells commence no sooner than 3 weeks following termination of pumping of distant extraction well 299-W11-45. The following seven T Tank Farm wells, listed in Table 2.1, are identified as having the highest monitoring priority during the recovery period: 299-W10-24, 299-W11-39, 299-W11-40, 299-W1142, 299-W11-45, 299-W11-46, and 299-W11-48. It is recommended that these wells be equipped with in-well pressure transducers and automated datalogger systems. Of the remaining wells listed in Table 2.1, the following priority ranking is provided. These wells can be monitored during the recovery based on availability of automated monitoring recording equipment: 299-W11-47, 299-W11-41, 299-W10-23, 299-W10-28, and 299-W10-33. 
It is recommended that the frequency of measuring the recovery of extraction well 299-W11-46 and nearby monitoring well 299-W11-39 (following termination of pumping) should closely follow that specified in Section 4.1 for measurement frequency at well 299-W11-45 following its pumping shutdown. Because of their greater distance from the extraction well location, the other five identified high priority monitoring wells will require a lower measurement frequency. To conserve manpower in the field for adjusting datalogger recording times, the in-well pressure measurements for these remaining high-priority wells may be recorded every 30 to $60 \mathrm{sec}$ for the first 8 hours of recovery and then adjusted to a frequency of every $15 \mathrm{~min}$ for recovery times $>8$ hours. A similar recording frequency can be adopted for the more distant lower priority monitoring wells (e.g., 299-W11-47). In the event of measurement/datalogger recorder failure during the first 8 hours of recovery, manual depth-to-water measurements (referenced to the well brass cap datum) should be taken as rapidly as possible and/or as recommended above. These manual measurements should be maintained during the recovery time period until automated readings can be re-established. For extended periods of datalogger/recording equipment failure, manual depth-to-water measurements should be maintained on a once-a-day basis until the automated readings can be re-established.

The estimated recovery period required to provide adequate time for assessing areal hydraulic properties within the 24-T Tank Farm area is difficult to predict because of its dependence on the prior pumping rate history, aquifer hydraulic/storage properties, well/aquifer penetration aspect relationships, and anisotropy within the unconfined aquifer system. However, based on semi-quantitative recovery simulations, it is recommended that the recovery period following termination of pumping of extraction well 299-W11-46 be conducted for a 1 to 2 month period.

\subsection{Extended Baseline Monitoring}

As part of baseline monitoring for assessing and removing barometric response characteristics, the same data set used to monitor recovery at monitoring wells following pumping termination at well 299-W11-46 will be analyzed for individual well/aquifer barometric response characteristics. This requires measuring the barometric pressure to be recorded at the same frequency and time as long-term, in-well recovery pressure readings (e.g., every $15 \mathrm{~min}$ ) at one or two of the monitoring well locations during the entire recovery period. Detailed examples of the barometric pressure evaluation and removal process for a neighboring 200-ZP-1 pump-and-treat monitor well system are provided in Spane and Thorne (2000).

\subsection{Re-Establishment of Pumping at 241-T Tank Farm Extraction Wells}

Following the monitored recovery period, pumping will be re-initiated at the 241-T Tank Farm pumpand-treat extraction wells. This initiation of pumping will produce an areal drawdown response that can also be monitored and analyzed to provide corroboration of the recovery/rebound characterization analysis. The monitoring of the pumping drawdown phase would mirror guidelines provided for the recovery characterization. In this instance, it is recommended that the pumping be re-initiated first at extraction well 299-W11-46, and the associated drawdown should be monitored at surrounding wells for a 1 to 2 month period. The same measurement frequencies as recommended in Section 4.2 would be relevant for this drawdown monitoring phase. It is recommended that after monitoring the associated drawdown response for a 1 to 2 month period, pumping at extraction well 299-W11-45 can be reestablished. 


\subsection{General Guidelines}

- All 241-T Tank Farm pump-and-treat performance information (e.g., pumping rate records, in-well drawdown data) should be collected and made available prior to termination of pumping at extraction well 299-W11-46

- All datalogger time systems and field clocks used for well recovery monitoring should be synchronized with official U.S. time (e.g. http://www.time.gov/timezone.cgi?Pacific/d/-8/java).

- Depth-to-water measurements should be taken within all wells monitored following termination of pumping at extraction well 299-W11-46. Depth-to-water measurements should accurately recorded with respect to time, specifically at the beginning, end, and periodically during (e.g., weekly, bi-monthly) the recovery phase.

- Field recovery datalogger systems should be downloaded on a daily basis during the first week of recovery following termination of pumping at well 299-W11-46.

- Accurate and detailed field notes should be maintained during all phases of the largescale recovery test 


\subsection{References}

DOE/RL. 1993. 200 West groundwater aggregate area management study report. DOE/RL92-16, Rev. 0, U.S. Department of Energy, Richland Operations Office, Richland, Washington.

DOE/RL. 2000. Fiscal year 1999 annual summary report for the 200-UP-1, 200-ZP-1, and 100-NR-2 pump and treat operations and operable units. DOE/RL-99-79, Rev. 0, U.S. Department of Energy, Richland Operations Office, Richland, Washington.

Li W, A Englert, OA Cirpka, and H Vereecken. 2008. "Three-dimensional geostatistical inversion of flowmeter and pumping test data." Ground Water 46(2), 193-201.

Newcomer, DR. 2007. Slug test characterization results for multi-test/depth intervals conducted during the drilling of CERCLA Operable Unit OU ZP-1 wells 299-W10-33 and 299-W11-48. PNNL-16945. Pacific Northwest National Laboratory, Richland, Washington.

Rasmussen TC, and LA Crawford. 1997. "Identifying and removing barometric pressure effects in confined and unconfined aquifers." Ground Water 35(3):502-511.

Spane FA, Jr. 1999. Effects of barometric fluctuations on well water-level measurements and aquifer test data. PNNL-13078, Pacific Northwest National Laboratory, Richland, Washington.

Spane FA, Jr. 2002. "Considering barometric pressure in groundwater flow investigations." Water Resources Research 38(6), 14:1-18.

Spane, FA and DR Newcomer. 2004. Results of detailed hydrologic characterization tests - FY 2003. PNNL-14804. Pacific Northwest National Laboratory, Richland, Washington

Spane FA., Jr., and DR Newcomer. 2008. Results of detailed hydrologic characterization tests fiscal and calendar year 2005. PNNL-17348, Pacific Northwest National Laboratory, Richland, Washington.

Spane FA, Jr., and PD Thorne. 2000. Analysis of the hydrologic response associated with shutdown and restart of the 200-ZP-1 pump-and-treat system. PNNL-13342, Pacific Northwest National Laboratory, Richland, Washington.

Spane FA, Jr., PD Thorne, and DR Newcomer. 2001a. Results of detailed hydrologic characterization tests - FY 1999. PNNL-13378, Pacific Northwest National Laboratory, Richland, Washington.

Spane FA, Jr., PD Thorne, and DR Newcomer. 2001b. Results of detailed hydrologic characterization tests - FY 2000. PNNL-13514, Pacific Northwest National Laboratory, Richland, Washington. 
Spane F.A, Jr., PD Thorne, and DR Newcomer. 2002. Results of detailed hydrologic characterization tests - FY 2001. PNNL-14113, Pacific Northwest National Laboratory, Richland, Washington.

Spane FA, Jr., PD Thorne, and DR Newcomer. 2003. Results of detailed hydrologic characterization tests - FY 2002. PNNL-14186, Pacific Northwest National Laboratory, Richland, Washington.

Vermeul VR, BN Bjornstad, CJ Murray, DR Newcomer, ML Rockhold, JE Szecsody, MD Williams, and Y Xie. 2004. In Situ Redox Manipulation Permeable Reactive Barrier Emplacement: Final Report - Frontier Hard Chrome Superfund Site, Vancouver, WA. PNWD3361, Pacific Northwest National Laboratory, Richland, Washington. 
PNNL-17433

\section{Distribution}

No. of

Copies

OFFSITE

3 Vista Engineering 8203 W. Quinault

Building C, Suite 200

Kennewick, Washington 99336

Attn: Ken Moser

Wes Bratton

Matt Tonkin
No. of

Copies

\section{ONSITE}

5 Flour Hanford, Inc.

M. E. Byrnes E6-44

D. G. Horton E6-35

J. G. Morse A6-38

V. J. Rohay E6-44

C. Swanson E6-35

A. C. Tortoso A6-38

4 Pacific Northwest National Laboratory

$\begin{array}{ll}\text { F. A. Spane (2) } & \text { K6-96 } \\ \text { T. J. Gilmore } & \text { K6-96 } \\ \text { D. R. Newcomer } & \text { K6-96 }\end{array}$

